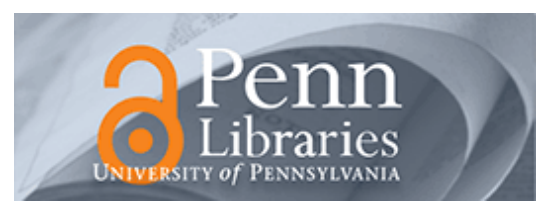

Manuscript Studies

Volume 2

Issue 1 Collectors and Collections in the History

of Thai Manuscripts

Article 4

2018

\title{
Thai Manuscripts in Italian libraries: Three Manuscripts from G.E. Gerini's Collection Kept at the University of Naples "L'Orientale"
}

Claudio Cicuzza

Lumbini International Research Institute, c.cicuzza@gmail.com

Follow this and additional works at: https://repository.upenn.edu/mss_sims

Part of the Medieval Studies Commons, and the South and Southeast Asian Languages and Societies Commons

\section{Recommended Citation}

Cicuzza, Claudio (2018) "Thai Manuscripts in Italian libraries: Three Manuscripts from G.E. Gerini's Collection Kept at the University of Naples "L'Orientale"," Manuscript Studies: Vol. 2 : Iss. 1 , Article 4. Available at: https://repository.upenn.edu/mss_sims/vol2/iss1/4

This paper is posted at ScholarlyCommons. https://repository.upenn.edu/mss_sims/vol2/iss1/4

For more information, please contact repository@pobox.upenn.edu. 


\title{
Thai Manuscripts in Italian libraries: Three Manuscripts from G.E. Gerini's Collection Kept at the University of Naples "L'Orientale"
}

\begin{abstract}
In this article I present a short description of the three illuminated Thai manuscripts kept in one of the libraries of the University of Naples "L'Orientale", the Biblioteca Maurizio Taddei. These three manuscripts contain various Buddhist jātakas and also non-canonical works, in Pali and in Thai. They are adorned with beautiful depicted images which have been here reproduced.
\end{abstract}

\section{Keywords}

Manuscript, Buddhism, Thai Buddhism, Buddha, karma, Jātaka, Script, Bodhisatta, Elephant, Astrology, Leporello books 
Cicuzza: Thai Manuscripts in Italian libraries: Three Manuscripts from G.E

\section{MANUSCRIPT STUDIES}

A Journal of the Schoenberg Institute for Manuscript Studies

VOLUME 2, NUMBER 1

(Spring 2017)

Manuscript Studies (ISSN 2381-5329) is published semiannually

by the University of Pennsylvania Press

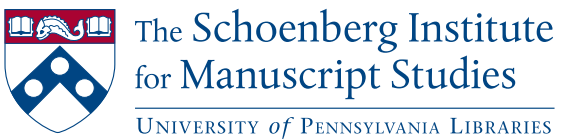




\section{MANUSCRIPT STUDIES}

VOLUME 2, N U M B E R 1

(Spring 2017)

\section{ISSN 2381-5329}

Copyright (C) 2017 University of Pennsylvania Libraries and University of Pennsylvania Press. All rights reserved.

Published by the University of Pennsylvania Press, 3905 Spruce Street, Philadelphia, PA 19104.

Printed in the U.S.A. on acid-free paper.

Manuscript Studies brings together scholarship from around the world and across disciplines related to the study of premodern manuscript books and documents, with a special emphasis on the role of digital technologies in advancing manuscript research. Articles for submission should be prepared according to the Chicago Manual of Style, $16^{\text {th }}$ edition, and follow the style guidelines found at http://mss.pennpress.org.

None of the contents of this journal may be reproduced without prior written consent of the University of Pennsylvania Press. Authorization to photocopy is granted by the University of Pennsylvania Press for libraries or other users registered with Copyright Clearance Center (CCC) Transaction Reporting Service, provided that all required fees are verified with CCC and paid directly to CCC, 222 Rosewood Drive, Danvers, MA 01923. This consent does not extend to other kinds of copying for general distribution, for advertising or promotional purposes, for creating new collective works, for database retrieval, or for resale.

\section{SUBSCRIPTION INFORMATION:}

Single issues: $\$ 30$

Print and online subscriptions: Individuals: $\$ 40$; Institutions: $\$ 90 ;$ Full-time Students: $\$ 30$ International subscribers, please add $\$ 18$ per year for shipping.

Online-only subscriptions: Individuals: \$32; Institutions: \$78

Please direct all subscription orders, inquiries, requests for single issues, address changes, and other business communications to Penn Press Journals, 3905 Spruce Street, Philadelphia, PA 19104. Phone: 215-573-1295. Fax: 215-746-3636. Email: journals@pobox.upenn.edu. Prepayment is required. Orders may be charged to MasterCard, Visa, and American Express credit cards. Checks and money orders should be made payable to "University of Pennsylvania Press" and sent to the address printed directly above.

One-year subscriptions are valid January 1 through December 31. Subscriptions received after October 31 in any year become effective the following January 1 . Subscribers joining midyear receive immediately copies of all issues of Manuscript Studies already in print for that year.

Postmaster: send address changes to Penn Press Journals, 3905 Spruce Street, Philadelphia, PA 19104.

Visit Manuscript Studies on the web at mss.pennpress.org. 
Cicuzza: Thai Manuscripts in Italian libraries: Three Manuscripts from G.E

\section{MANUSCRIPT STUDIES \\ A Journal of the Schoenberg Institute for Manuscript Studies}

VOLUME 2, NUMBER 1

Special Issue:

Collectors and Collections in the History of

Thai Manuscripts

Guest Editor: Justin McDaniel

Dedication

\section{Articles}

Illuminating Archives: Collectors and Collections in the History of Thai Manuscripts

Justin MCDANieL

Henry D. Ginsburg and the Thai Manuscripts Collection at the British Library and Beyond

JANA Igunma

Cultural Goods and Flotsam: Early Thai Manuscripts in Germany and Those Who Collected Them

Barend Jan Terwiel

Thai Manuscripts in Italian Libraries: Three Manuscripts

from G. E. Gerini's Collection Kept at the University of

Naples "L'Orientale"

Claudio Cicuzza

Manuscripts in Central Thailand: Samut Khoi from

Phetchaburi Province

Peter Skilling and Santi Pakdeekham

Manuscripts from the Kingdom of Siam in Japan

Toshiya Unebe 
Manuscript Studies, Vol. 2 [2018], Iss. 1, Art. 4

iv | Journal for Manuscript Studies

The Chester Beatty Collection of Siamese Manuscripts in Ireland

Justin MCDAniel

Siamese Manuscript Collections in the United States

Susanne Ryuyin Kerekes and Justin McDaniel

\section{Reviews}

Michael Johnston and Michael Van Dussen, eds. The Medieval Manuscript Book: Cultural Approaches

Benjamin C. Tilghman

Christopher Wright, Maria Argyrou and Charalambos

Dendrinos. A Descriptive Catalogue of the Greek Manuscript

Collection of Lambeth Palace Library

Georgi Parpulov

Orlanda S. H. Lie, Martine Meuwese, Mark Aussems, Hermina Joldersma. Christine de Pizan in Bruges: "Le livre de la cité des dames" as "Het Bouc van de Stede der Vrauwen"

Hanno Wijsman

York's Archbishops' Registers Revealed

Alexander Devine

Beyond Words: Illuminated Manuscripts in Boston Collections, and Jeffrey F. Hamburger, William P. Stoneman, Anne-Marie Eze, Lisa Fagin Davis, and Nancy Netzer, eds. Beyond Words: Illuminated Manuscripts in Boston Collections

Jessica BrantLey

List of Manuscripts Cited 


\section{Thai Manuscripts in Italian Libraries \\ Three Manuscripts from G. E. Gerini's Collection Kept at the University of Naples "L'Orientale"}

Claudio Cicuzza

Lumbini International Research Institute

he three illuminated Thai manuscripts I am describing in this article, dating from the late nineteenth century, are now kept in the Biblioteca Maurizio Taddei located in the Department of Asian Studies at the University of Naples "L'Orientale." They were originally part of the collection belonging to Colonel Gerolamo Emilio Gerini (1869-1913), and were donated to the Istituto Orientale Universitario during the 1950s. ${ }^{2}$ There are other Thai manuscripts kept in Italian libraries (Rome, Venice, Cagliari, and so on), and the study of those codices will be the object of forthcoming studies.

This is a deeply revised version of an article entitled "The Buddha, Letters, and Time," Franco Maria Ricci 2008 (28): 109-28. The photos are by Luciano Pedicini. All the Pali texts are quoted from the editions by the Pali Text Society.

1 For a heartfelt description of Maurizio Taddei's contribution to the Institute of Oriental Studies in Napoli, see Giovanni Verardi, "Necrologio," Annali dell'Università degli Studi di Napoli "L'Orientale" 60-61 (2001): 531-41. A complete list of his works and an intimate description of his personality can be found in Gherardo Gnoli, "Maurizio Taddei, 1936-2000," East and West 50.1-4 (2000): 544-64.

2 On the life and the work of G. E. Gerini, see Luciano G. Gerini, Kanokwan Rittipairoj, and Judith Arndt, eds., G. E. Gerini and the Mosaic of Genius (Bangkok, 2005). 
The three manuscripts at the University of Naples "L'Orientale" contain various canonical Buddhist texts and non-canonical works, in Pali and in Thai.

There is epigraphic, archaeological, and literary evidence telling us, with some degree of certainty, that Buddhism in Thailand arrived independently of Sinhalese Buddhism, and that it can be dated back to the missionaries sent to Southeast Asia at the time of the third Buddhist council, during the reign of King Aśoka (third century BC). ${ }^{3}$ According to the Sinhalese chronicle Mabāvamsa, certain masters, who had set off to spread the teachings of the Buddha, also reached regions later to be identified as areas of Southeast Asia. ${ }^{4}$

The Pali texts of the Buddhist canon (tipitaka), together with their commentaries, were not written down until after the first council, held in Sri Lanka during the reign of Vațtagāminī Abhaya (second half of first century $\mathrm{BC}$ ), some four hundred years after the Buddha's death. In the Sinhalese chronicles Mahāvamsa and Dippavamsa, we read: "Before this period [the reign of Vațtagāminī Abhaya], various learned monks had handed down the texts of the Three Pitaka orally, together with their respective commentaries. Now, however, since they observed a deterioration [in the wholesome qualities] among living beings, the monks met together and had the corpus of the canonical texts written down in books, to enable the Dhamma to endure."

3 See Prapod Assavavirulhakarn, The Ascendency of Theravāda Buddhism in Southeast Asia (Chiang Mai: Silkworm Books, 2010), 60-62, and Peter Skilling, "The Advent of Theravāda Buddhism to Mainland Southeast Asia," in Claudio Cicuzza, ed., Peter Skilling: Buddhism and Buddhist Literature of South-East Asia. Selected Papers (Bangkok and Lumbini: Fragile Palm Leaves and LIRI, 2009), 114.

4 Mahāvaṃsa, XII, 44-45. See also Wilhelm Geiger, trans., and Mabel Haynes Bode, asst., The Mahävamsa of the Great Chronicle of Ceylon (1912; repr. Oxford: Pali Text Society, 2001), 86.

5 Mahāvaṃsa, XXXIII, 102-3, and Dīpavaṃsa, XX, 20-21. I interpret the term bāni as "deterioration" following Bhikkhu Bodhi's translation of the "Standstill sutta" (AN V, 96-98), which seems to be particularly pregnant in this context. See Bhikkhu Bodhi, The Numerical Discourses of the Buddha (Somerville, MA: Wisdom Publications, 2012), 1403-4, and 1844, n. 2062. Another possible translation is: "decrease [of the number of living beings]." 


\section{Cicuzza: Thai Manuscripts in Italian libraries: Three Manuscripts from G.E}

\section{8 | Journal For Manuscript Studies}

So, according to the Sinhalese historiographical tradition, over the first centuries of its life the Buddhist canon was handed down mainly by word of mouth. This hypothesis would indeed seem to be confirmed by the absence of written sources prior to the third century BC, the time of the epigraphic evidence dating from the reign of King Aśoka. Even if writing is known to have existed at an earlier date, its use was probably restricted to limited fields, mainly to do with trade and law, and it does not seem to have been used for the drafting of religious or philosophical texts. ${ }^{6}$ We also know that the task of committing the canon to memory was entrusted to monks known as bhānaka, or "reciters," who probably concentrated on, and recited, certain selected parts of the canon.

However, alongside the fact that the canon was transmitted by being committed to memory and recited, we can also assume that manuscripts were already being used prior to the canon's supposed drafting in the first century BC, probably serving as the basis for this same memorizing and recitation. $^{7}$

What were the reasons for this restricted use of writing in Buddhism, at least during the first centuries of its history? Any attempt to answer this question means turning our attention to India, the cradle of Buddhism, where there had always been a preference for knowledge in oral form. ${ }^{8}$

6 See Kenneth Roy Norman, A Pbilological Approach to Buddhism (Lancaster, Pa.: Pali Text Society, 2006), 103.

7 See John Brough, The Gāndhārī Dharmapada (London: Oxford University Press, 1962), 218. See also Peter Skilling, "Redaction, Recitation, and Writing: Transmission of the Buddha's Teachings in India in Early Period," in Stephen C. Berkwitz, Juliane Schober, and Claudia Brown, Buddbist Manuscript Cultures: Knowledge, Ritual, and Art (London: Routledge, 2009), 53-75 at 62: "Thus, both Tārānātha and Butön agree that the writing of texts began after the 'third council.' The fact that Tārānātha discusses the writing down of the Tripitaka has not generally been recognized because the passage is mistranslated in the only available English translation. Tārānātha's account points to a gradual writing of the texts and a later standardization, both of which seem natural and plausible."

8 There are numerous fundamental studies written on this crucial theme: see, for instance, Madhav M. Deshpande, "From Orality to Writing: Transmission and Interpretation of Pāninini's Aștādhyāyī," in Travaux de Symposium International Le Livre. La Roumanie. L'Europe. Tome III: la troisième section. Études Euro- et Afro-asiatiques (Bucharest: Bibliothèque de Bucarest, 2011), 57-100; Madhavi Kolhatkar, "Orality and Authenticity," in 
Among the Brahmins - who tended to monopolize knowledge, keeping it confined within firmly demarcated cultural and geographical borders-at least until the tenth century $\mathrm{AD}$ the written text was denied the authority it enjoyed not only in the West, but also in other great Eastern civilizations, such as China. Light is cast on this attitude by the phrase often quoted in Sanskrit manuals for beginners: "Knowledge written in a book is neither more nor less than wealth in another's hands." The only firm and reliable knowledge is located in the throat (kanthastha) and not in the books (granthastha).$^{10}$ Even if Brahmins' resistance to writing is undeniable, it still seems likely that manuscripts were sometimes used, in the main centers of study, and in monasteries, as a basis for quotations and philosophical debates, which would have been problematic without the support of written texts. $^{11}$

If we may therefore assume that the writing of manuscripts was possible within the Hindu tradition, we may regard it as more than probable in the Buddhist monastic centers. ${ }^{12}$ Aiming to reach beyond India's borders, Buddhism had always been opposed to the cultural and social boundaries put up by the Brahmanic world; in this desire to propagate the word of the Buddha among different peoples, with their different languages, the use of

Travaux de Symposium International Le Livre. La Roumanie. L'Europe, vol. 3, La troisième section. Études Euro- et Afro-asiatiques (Bucharest: Bibliothèque de Bucarest, 2011), 212-19, Madhav M. Deshpand, "Brahmanism Versus Buddhism: A Prospective of Language Attitudes," in N. N. Bhattacharyya, ed., Jainism and Prakrit in Ancient and Medieval India: Essays for Prof. Jagdish Chandra Jain (New Delhi: South Asia Books, 1994), 89-111, Skilling, "Redaction, Recitation, and Writing," 53-75, Raffaele Torella, "Oral and Writing," in The Philosophical Traditions of India. An Appraisal (Varanasi: Indica Books, 2011), 197-211.

9 Quoted in Torella, The Philosophical Traditions of India, 205.

10 See Sheldon Pollock, The Language of the Gods in the World of Men: Sanskrit, Culture, and Power in Premodern India (Berkeley: University of California Press, 2006), 82.

11 "Sanskrit culture ... was centrally based on writing, given the idée reçu[e] long dominant in Indology of culture's allegiance to orality." See Pollock, The Language of the Gods in the World of Men, 83.

12 In later periods, the gift of a manuscript together with the gift of a divine image and the gift of teaching became known as the "three gifts of knowledge" (vidyādāna). See K. V. Sharma, "Propagating of Written Literature in Indian Tradition," Adyar Library Bulletin 57 (1993): 20. 


\section{Cicuzza: Thai Manuscripts in Italian libraries: Three Manuscripts from G.E}

\section{0 | Journal For Manuscript Studies}

a written text was clearly of fundamental importance: "Manuscript can travel, can reach remote outposts, endure as a potential repository of wisdom, awaiting to be brought again to life by a reader, or a master who will recite it and comment upon it; or simply remain, as a worship object, a silent testimony that the Buddha's teachings have once occurred."13

The writing of new manuscripts, the composing of commentaries, and the reciting of the texts were, and are still, extremely closely related and underpinned by similar motivations: the main one was undoubtedly ethical in nature, namely the pursuit of spiritual merit on the part of their owners, for both themselves and their loved ones, earned as a result of the drafting, or causing to be drafted, of one such manuscript, from reading it, and from listening to it. Thus the manuscript is a means of guaranteeing oneself and others a higher form of rebirth, a fact that also caused it to be an object of veneration.

The words of the Awakened One, carved into palm leaves, also represent all that remains of him, embodying his teachings. One canonical text reads as follows: "[After my death], the Dhamma and the discipline I have taught will be your teacher." ${ }^{14}$ The very letters of the manuscript represent the Buddha, as though they held within them not just a sound, not just his thought, not just the explanation of the spiritual life that led him to Nibbāna, but even the very power to evoke his presence. The colophons of Burmese manuscripts often contain the following stanza: "May every letter, one by one, be regarded as an image of the Buddha [buddharüpa], and for this reason the Tipițaka must be written down by a wise man."15

13 Torella, The Pbilosopbical Traditions of India, 204-5 (the text-formerly a revised translation from an original book chapter in Italian-has been slightly modified by myself).

14 See Digghanikāya 16.6.1 (PTS II, 154). A translation of the entire sutta is available in Rupert Gethin, Sayings of the Buddha: New Translations by Rupert Gethin from the Pali Nikayas, (Oxford: Oxford University Press, 2008), 88. The translation of the commentary on this passage has been published by Yang-Gyu An in The Buddha's Last Days: Buddhaghosa's Commentary on the Mabāparinibbāna Sutta (Oxford: Pali Text Society, 2003), 176-79. See also Dīghanikāya 16.2.26 (PTS II, 101) and 26.1 (PTS III, 58).

15 See Dhammasamgaha X, 3-4, ed. Nedimāle Saddhānanda, Journal of the Pali Text Society (1890): 65. See also Claudio Cicuzza, ed., Peter Skilling: Buddhism and Buddhist Literature of South-East Asia. Selected Papers (Bangkok and Lumbini: Fragile Palm Leaves and LIRI, 2009), 


\section{Manuscript Studies, Vol. 2 [2018], Iss. 1, Art. 4}

Thus a manuscript is regarded as sacred because it contains the Buddha himself, just as a cetiya (a sepulchral monument, or shrine) is regarded as sacred because it may contain the relics of the Buddha. This notion can be analogously applied to an image, or to some physical manifestation of his past presence, such as his footprint (buddhapāda): their veneration leads to an accumulation of spiritual merit, and hence to positive results in this or future lives. ${ }^{16}$ The word most used in Thailand to translate "sacred," saksid (ศักดิ์สิทธิ์), implies an extreme form of "strength," or "capacity for realization," itself one of the functions of the text, of which we shall say more anon. In the Lanna and Laotian Buddhist tradition, for example, the person who looks after the sacred texts is "empowered" by his position, and must be revered and respected by all as though he himself were a relic of the Buddha. ${ }^{17}$

The writing and reading aloud of a text are not always or necessarily linked to the simple literal meaning of the work that they transmit. The text, whether written or read aloud, is also regarded as capable of unleashing a power produced by the very phonemes that make it up, a power that protects both those who write it and those who recite it, and indeed those who listen to it, irrespective of the meaning conveyed. Thus the oral and written traditions not only are used to transmit the scriptures, but also

61, and Daniel M. Veidlinger, Spreading the Dhamma: Writing, Orality, and Textual Transmission in Buddhist Northern Thailand (Honolulu: University of Hawai'i Press, 2006), 177.

16 See Donald K. Swearer, Becoming the Buddha: The Ritual of Image Consecration in Thailand, (Princeton, NJ: Princeton University Press, 2004) and, for an analysis more focused on Indian Buddhism, see also Andy Rotman, Thus Have I Seen (New York: Oxford University Press, 2009), and Robert DeCaroli, Image Problems: The Origin and Development of the Buddha's Image in Early South Asia (Seattle: University of Washington Press, 2015), 136-45. On the buddhapāda tradition in Thailand and Southeast Asia, see Claudio Cicuzza, A Mirror Reflecting the Entire World: The Pāli Buddhapädamangala or "Auspicious Signs on the Buddha's Feet," critical ed. with English translation (Bangkok: Fragile Palm Leaves Foundation and LIRI, 2011).

17 This characteristic of the recitation of the Buddhist texts has been analyzed by Justin McDaniel in his The Lovelorn Ghost and the Magical Monk: Practicing Buddbism in Modern Thailand (New York: Columbia University Press, 2011), 72-120. For a more anthropological analysis of this theme, see Hayashi Yukio, Practical Buddhism Among the Thai-Lao: Religion in the Making of a Region (Kyoto: Trans Pacific Press, 2003), 196-303. 


\section{Journal For Manuscript Studies}

serve as a form of aegis, or protection, so that the literal meaning becomes almost secondary. Recitation, for example, is sometimes carried out by several monks who read out the manuscripts simultaneously, thus making the comprehension of the text rather difficult: this happens, for example, when the Vessantarajātaka-one of the texts most revered throughout Southeast Asia-is read out (Thet Mabāchāt, เทศมหาชาติ), subdivided into various sections, by various monks who occasionally recite them at the same time. ${ }^{18}$

In Thailand, the oldest manuscripts date from the fifteenth century, and were originally produced in the north of the country, in what was the kingdom of Lanna. ${ }^{19}$ Northern manuscripts are usually unadorned, written on palm leaves, and generally have no images but contain only the text; they are protected by two wooden rods (mai prakap, ไม้ประกับ) that contain all the leaves, and are kept in closets (bip, หีบ), about a square meter in size, either in monasteries or in traditional libraries. ${ }^{20}$

The three manuscripts that concern us here, on the other hand, are from Central Thailand. Most extant manuscripts from this area were made during the Ratanakosin period (1768-1932), their production being encouraged by various factors, including probably that of the influence of the culture of the north. They are usually anonymous.

The manuscript volumes illustrated here are called samut kboi (สมุด ข่อย), and are written on paper, a support that is obviously greatly superior to palm leaves when it comes to the making of images, or other little works of art accompanying the texts. A samut kboi may be written on black paper

18 See G. E. Gerini, The Thet Maha Chat Ceremony (Bangkok: Sathirakoses Nagaprateepa Foundation, 1976).

19 See Oskar von Hinüber, "On Some Colophons of Old Lanna Pali Manuscripts," Proceedings of the 4th International Conference on Thai Studies, 11-13 May 1990, vol. 4 (Kunming: Institute for Southeast Asian Studies, 1990), 56-77.

20 Useful information about illustrated samut kboi and the topics they depict can be found in the following two important works by Henry Ginsburg: Thai Manuscript Painting (London: British Library, 1989), and Thai Art and Culture: Historic Manuscripts from Western Collections (Chiang Mai: Silkworm Books, 2000). See also Daniel M. Veidlinger, Spreading the Dhamma: Writing, Orality, and Textual Transmission in Buddhist Northern Thailand (Honolulu: University of Hawai'i Press, 2006), 103-32. 
(samut khoi dam, สมุดข่อยดำ) or on white (samut khoi kbao, สมุดข่อยขาว): the white paper is made from the bark of the mulberry tree, mixed with a solution of lime and glue, obtained from flour. The manuscripts were copied by monks, though the profession of "monk-copyist" did not really exist, nor were there any scriptoria. Furthermore, the monks worked only during the rainy season, when it was customary for them to retire into their monasteries.

Manuscripts were usually commissioned and financed by donors and ruling sovereigns, regarded as defenders of the Dhamma (dhammarāja), for the acquiring of spiritual merit (puññ), and to demonstrate the close links that existed between religion and their own authority, thereby also enhancing their own charisma among their subjects.

The first manuscript contains a section of the third part of the Tipitaka, known as Abhidhammapitaka, "the basket of things relating to the Teachings" or "the Higher Teaching." ${ }^{21}$ It consists of one single long sheet of paper, folded into an accordion-pleat style, with writing on both sides in the samut khoi style. ${ }^{22}$ The splendid illuminations in this manuscript are inspired by a section of the Buddhist canon known as jātaka, which tells of the events of the Buddha's past lives. ${ }^{23}$

The idea that each individual has had an infinite number of past lives, and that our present existence is morally linked to them, is indeed a consequence of them, has its roots in the well-known idea that all of men's conscious actions (karma) generate an unceasing dynamic that, with positive or negative consequences according to the nature of the acts performed, will fatally bound the individual, affecting his present life and those of the

21 For "the basket of ...," see Oskar von Hinüber, A Handbook of Pāli Literature (1996; repr. New Delhi: Munshiram Manoharlal, 1997), 64. For “the Higher Teaching . . ., see Rupert Gethin, The Foundations of Buddhism (Oxford: Oxford University Press, 1998), 202.

22 The accordion-pleat style of folding is sometimes also known as "concertina fold" or "leporello."

23 A very accurate description of similar images in another Thai manuscript has been offered by Naomi Appleton, Sarah Shaw, and Toshiya Unebe in their superb volume Illuminating the Life of the Buddha. An Illustrated Chanting Book from Eighteenth-Century Siam (Oxford: Bodleian Library, University of Oxford, 2013). 


\section{Cicuzza: Thai Manuscripts in Italian libraries: Three Manuscripts from G.E}

\section{4 | Journal For Manuscript Studies}

future, for good or ill. A famous stanza that often appears in Buddhist literature runs as follows: "Even over hundreds of cosmic ages, deeds never disappear: when the completeness [of conditions] and the right moment have been reached, then they will surely bear fruit to the embodied beings." ${ }^{24}$

The stories told in the jätakas belonged to a very ancient narrative tradition, and were adapted piecemeal to the ethics and doctrines of Buddhism; their aim was to encourage ordinary men to cultivate the moral virtues in order to obtain ultimate liberation from the samsāra. We find some of these stories depicted on the bas-reliefs on the stūpas at Bhārhut and Sāñchī as early as the third and second centuries BC, and they are broadly similar in outline to the jātakas of the Pali collection. The jätakas depicted in the illuminations of this manuscript belong to the last subdivision of the collection, known as Mahānipāta, which contains ten jātakas, each teaching and glorifying a perfection (pāramì) of the Buddha. In each we find the presence of a divinity, usually Sakka (in Buddhist texts in Pali, he corresponds to the Vedic god Indra), who seems to weave the outline of the narrative. Even if the situations thus created seem to be almost hopeless, his intervention-brought on by the truthful and sincere words uttered by one of the protagonists-ensures that the story's outcome will in fact be positive.

Figure 1 is taken from the Mügapakkbajātaka (or Temi[ya]jātaka), which tells of the perfection of determination (adbitthbana). ${ }^{25}$ The protagonist is Prince Temiya — the Bodhisatta—who, prompted by a divinity, decides to pretend that he is a crippled mute, and therefore unsuited to becoming a

24 "Na praṇaśyanti karmāṇy api kalpaśatair api | sāmagrīṃ prāpya kālaṃ ca phalanti khalu dehinām." See Raniero Gnoli, ed., The Gilgit Manuscript of the Śayanāsanavastu and the Adbikaraṇavastu (Rome: IsMEO, 1978), 69, and Divyāvadāna (see Andy Rotman, Thus Have I Seen [New York: Oxford University Press, 2009], 278-79, n. 60). See also Étienne Lamotte, Le Traité de l'Acte de Vasubandhu. Karmasiddhiprakaraṇa (Bruges, Belgium: Imprimerie Sainte Cathérine, 1936), 226. On the motivations or intentions that generate human actions, see the interesting analysis by Maria Heim in The Forerunner of All Things: Buddhaghosa on Mind, Intention, and Agency (Oxford: Oxford University Press, 2014), 83-131.

25 See Jätaka-atthakathā, VI, 1-30. Translated by E. B. Cowell in The Jātaka or Stories of the Buddha's Former Births, vol. 6 (1907; repr. Oxford: Pali Text Society, 2005), 1-19. 


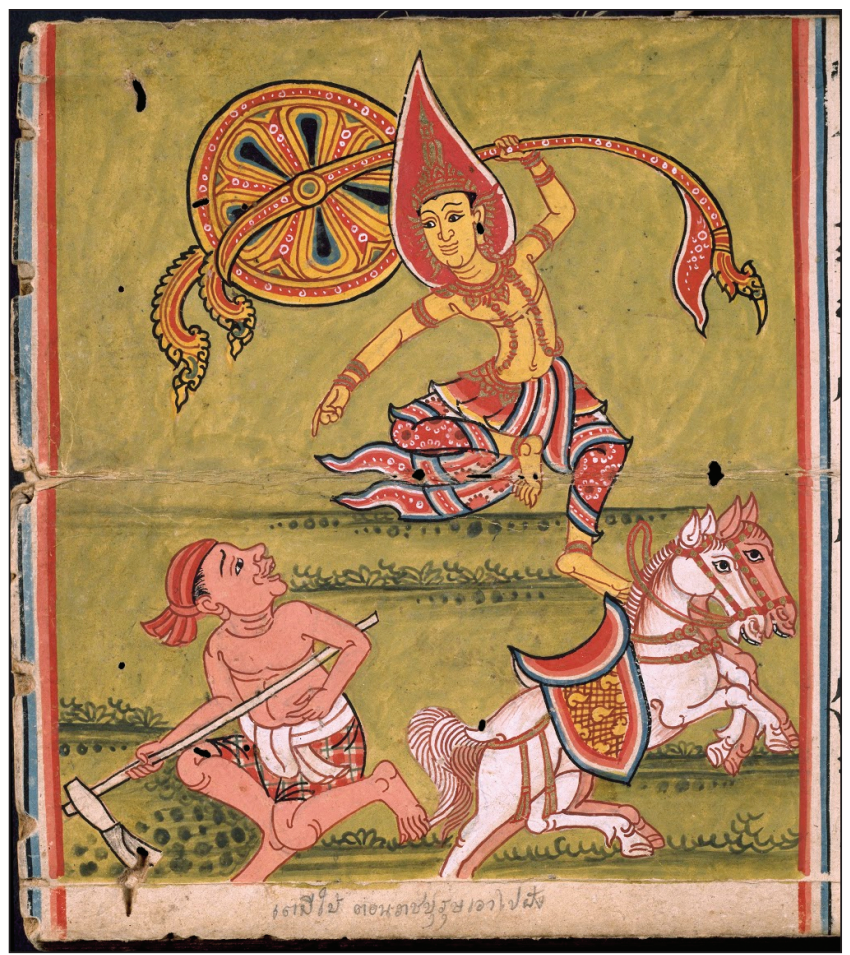

FIGURE 1. Scene from the Temiya Jätaka. Sunanda digging the grave where Temiya will be laid. Maurizio Taddei Library, uncatalogued manuscript, Ratanakosin period. Photo courtesy of Luciano Pedicini.

ruler. In fact, he feared that if he did, he would be obliged to perform cruel deeds - as had his father and himself in one of his previous lives-and would be reborn into one of the transitory hells. Sixteen years later, the king decided to send his only son off to be killed, and have his body buried by Sunanda, his faithful charioteer, because by now he had lost all hope of seeing him succeed him to the throne. In the scene shown here, we see Sunanda digging the grave where Temiya will be laid. But at that very moment, the prince decides to speak out and tell Sunanda that he wishes to embark upon the ascetic life. When Sunanda heard Temiya's words, he was so impressed that he immediately wished to become an ascetic himself. 
Cicuzza: Thai Manuscripts in Italian libraries: Three Manuscripts from G.E

116 | Journal for Manuscript Studies
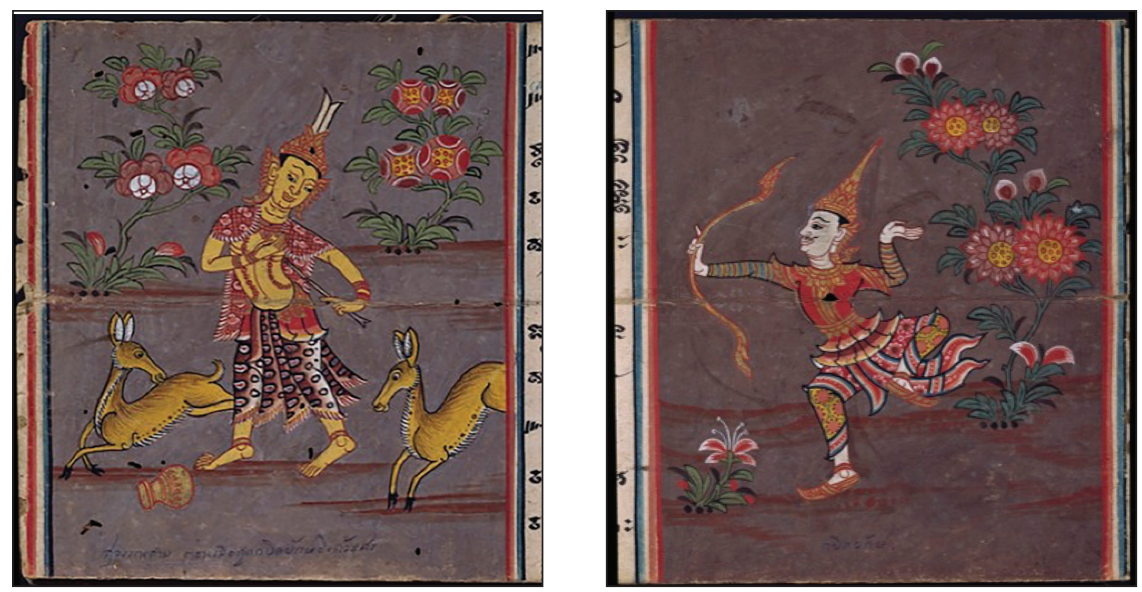

FIGURES 2 (LEFT) AND 3 (RIGHT). Scenes from the Suvannasāma Jātaka.

Suvaṇnasāma is pierced by an arrow shot by King Piliyakkha. Maurizio Taddei Library, uncatalogued manuscript, Ratanakosin period, Photo courtesy of Luciano Pedicini.

Figures 2 and 3 are inspired by the Suvannasāmajātaka, which tells of the perfection of love $(m e t t \bar{a}) .{ }^{26}$ This jātaka narrates the story of the birth of the Bodhisatta as Sāma or Suvannasāma, so called because his skin was the color of gold (suvanna). He had taken on care of his parents after they had been blinded by a poisonous snake, thereby giving proof of particularly devoted love and dedication. While he was filling a water jar, Suvaṇnasāma was glimpsed by Piliyakkha, the king of Benares. Seeing his golden skin, and noting that two nearby deer did not seem to be remotely frightened by his presence, Piliyakkha immediately thought that he must be a god. So he let fly a poisoned arrow, which struck Suvannnasāma in the side, causing him to faint and fall into a coma. He was watched over in his unconscious state by a divinity-Bahusodarī, who had been Suvaṇnasāma’s mother seven births earlier-who kept him from all harm. This same divinity persuaded King Piliyakkha to go and find Suvannnasāma's parents to tell them what had happened, and to ask their forgiveness. Suvaṇnasāma's parents did not

26 See Jātaka-ațthakathā, VI, 68-95. Translated by E. B. Cowell in The Jätaka or Stories of the Buddha's Former Births, vol. 6 (1907; repr. Oxford, 2005), 38-52. 
Manuscript Studies, Vol. 2 [2018], Iss. 1, Art. 4

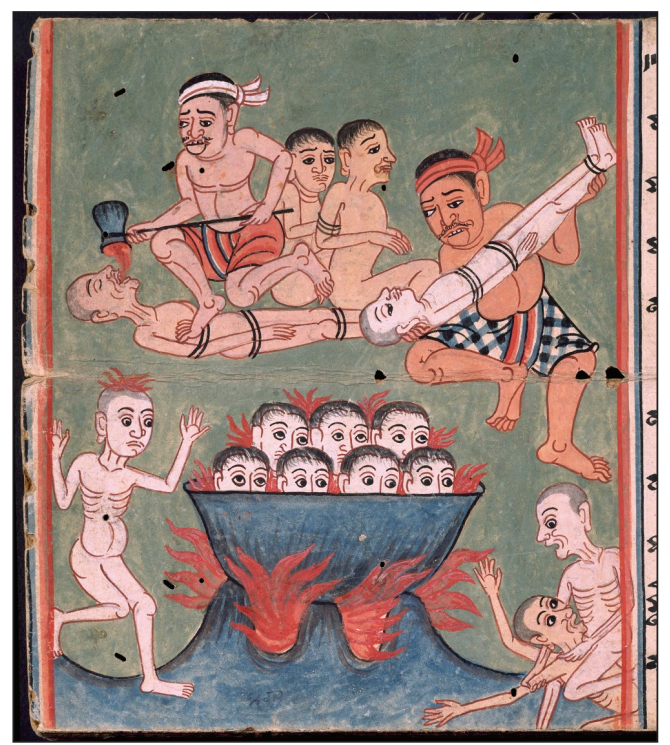

FIGURE 4. Scene from the Nimi Jätaka depicting one of the transitory hells (naraka). Maurizio Taddei Library, uncatalogued manuscript, Ratanakosin period. Photo courtesy of Luciano Pedicini.

say one word of resentment, and they absolved Piliyakkha. Suvannnasāma regained consciousness, and his parents, who had expressed no ill will toward King Piliyakkha, regained their sight.

Figure 4 is from the Nimijätaka, one of the most frequently depicted in wall paintings, fabrics and manuscripts, mainly because of its descriptions of the transitory hells (naraka), one of which is indeed shown here. ${ }^{27}$ This jātaka tells of the pāramī of altruistic sacrifice and renunciation (nekkhamma). King Nemi, tormented by doubt as to how to choose between the right path as a sovereign, and a life devoted to spiritual endeavour, received a visit from the god Sakka, who encouraged him to follow the rules of morality and make offerings to the monks. ${ }^{28}$

27 For the Nimijātaka, see Jätaka-ațthakatbā, VI, 95-129.

28 Nemi is another form of the name Nimi. 
Sakka then asked his charioteer to accompany King Nemi to the world of the thirty-three gods, the "Tāvatimsa Heaven," and during the journey the sovereign also expressed a desire to visit the transitory hells and paradises. On his return to Mithila, the capital of his kingdom, Nemi proved to be an excellent king until his first white hair appeared; at that point, like his father before him, he renounced the throne and devoted himself to a life of asceticism.

Figure 5 is from the Candakumārajātaka (or Khandahälajātaka), which tells of the parami of patience (kbanti). ${ }^{29}$ Prince Canda, the son of king Ekarājā, was particularly admired for his great patience and wisdom. The court brahmin, Kaṇdahāla, envious of the prince's reputation, decided to do all he could to ruin the latter's life. When the king expressed his desire to visit the world of the thirty-three gods, Kaṇ̣ahāla suggested that he sacrifice all that he possessed-kingdom, possessions, and so on-including the life of his son. Blinded by his desire to visit the heaven of the thirtythree gods, and going against the advice of his other counselors, the king duly organized this great sacrifice; but just as the drama was about to unfold, the god Sakka suddenly sprang into action, moved by the truthful and sincere words of Queen Candā. Brandishing a parasol, he prevented the prince from being killed, allowed the people to rebel, freed the prisoners, sent the king into exile, and meted out just punishment to the court brahmin.

The second manuscript, also a samut kboi, deals with cosmology. This science is particularly important in the Theravāda Buddhism of Southeast Asia because it serves as the theoretical basis for architecture, mythology, astrology, and their depiction in paintings on walls, fabrics, and manuscripts. From the eleventh century onward there was a huge outpouring of texts in Pali devoted to astronomy and astrology, above all in the Siamese tradition. These were followed, in the fourteenth century, by works describing the three worlds (ไตรภูมิ, traiphum), written in Thai and Khmer. The text to which we might refer for the interpretation of these very lovely

29 See Jātaka-ațthakathā, VI, 129-57. 
Manuscript Studies, Vol. 2 [2018], Iss. 1, Art. 4

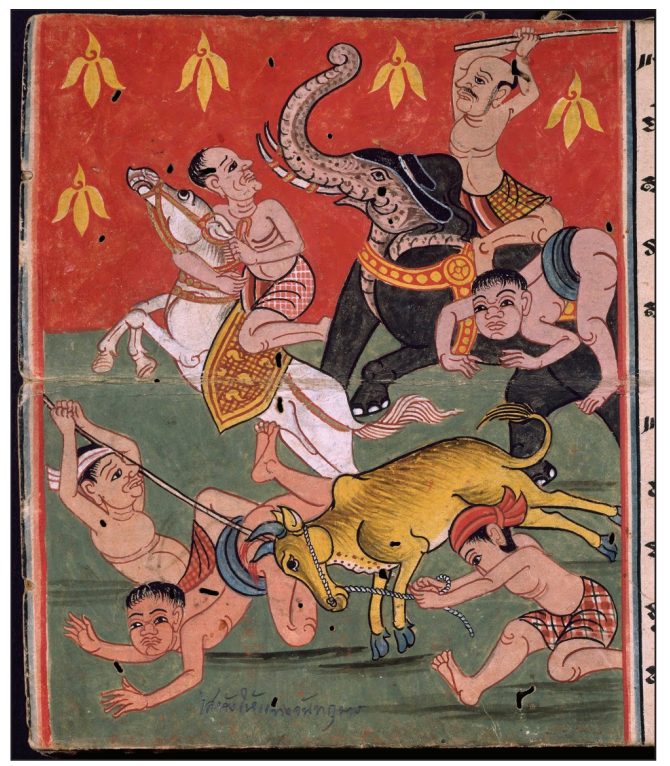

FIGURE 5. Scene from the Candakumāra Jätaka of the foiled attempt to kill Candrakumāra.

Maurizio Taddei Library, uncatalogued manuscript, Ratanakosin period. Photo courtesy of Luciano Pedicini.

images is the Traiphumikatha , written in 1344 by Lithai, the future king of Sukhotai. ${ }^{30}$

The first part of this manuscript contains a description of the personalities and inclinations of people born under the signs of the zodiac, represented by twelve animals, here illustrated in combination with the five traditional Chinese elements, namely wood, fire, earth, metal, and water.

30 King Lithai, ไตรภูมิกถา. Traibhumikatha: The Story of the Three Planes of Existence (in Thai and English translation by Panit Boonyawanna) (Bangkok: ASEAN, 1987). See also Frank E. Reynolds and Mani B. Reynolds, Three Worlds According to King Ruang: A Thai Buddhist Cosmology (Berkeley: Center for South and Southeast Asian Studies, University of California, 1982), and George Coedès and Charles Archaimbault, Les trois mondes (Traibhūmi Brạ̣ Rvañ) (Paris: École française d'Extrême-Orient, 1973). 


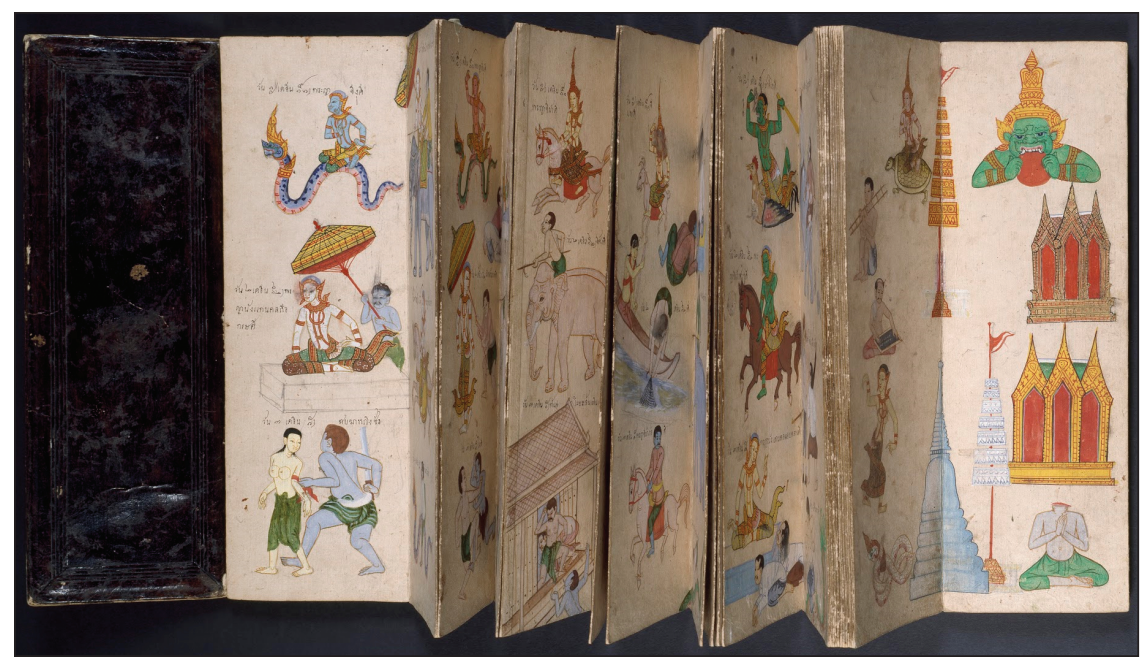

FIGURE 6. A samut khoi manuscript on cosmology, based on the Traiphumikathā. Maurizio Taddei Library, uncatalogued manuscript, Ratanakosin period. Photo courtesy of Luciano Pedicini.

The second part describes the charting of the astral picture of a person from the moment of his or her birth, and, on this basis, the likelihood of how one will get on with another, a likelihood itself regulated by precise astrological principles, together with the more or less happy events that may occur during the year (see figure 6).

This interest in the external world, and in the dynamics of the cosmos generally, together with the study of the link existing between the human macrocosm and microcosm and its physical, mental, and even moral components, may seem complex to Western eyes. We should, however, remember that Buddhist philosophical schools always tend to find connections between microcosm and macrocosm, and that the mental aspect was never separated from the more truly physical, even if there is naturally an awareness that such a division is necessary and useful in daily life. It is "something that lies at the heart of Indian Buddhism thought, namely, a basic ambiguity about matters of cosmology and psychology, about the objective outer world and the subjective inner world. ... The notion 'world' is just like the notion of 'self': it is not of itself an ultimately real thing but merely a con- 
cept, a mental construct." ${ }^{11}$ The study of the external world, and of the laws that govern its unfolding, becomes an instrument for the understanding of our inner life, and may be of help in the spiritual journey toward liberation.

The last manuscript, too, is another samut khoi, written at the beginning of the nineteenth century on one of the topics dearest to the Siamese world - that is, the knowledge and definition of the "noble" elephant on the basis of certain specific aesthetic and behavioral norms (gajalakșana, in Thai คชลักษณ์). ${ }^{32}$ Several of its pages are written in gold ink, obtained by mixing the yellow pigment known as rong (รง) with a mineral known as horadan klip thong หรดาล ขลิบทอง, that is, arsenic trisulphide).

According to Thai tradition, the rare white elephant (chang pheuak, ช้าง เผือก) symbolizes prosperity for the entire country, probably because it was originally associated with water, and more particularly rain. In 1921 King Vajiravudh (Rama VI) passed a bill for the preservation of wild elephants that also contains detailed characteristics and precise canons to detect during the examination of a chang pheuak: even today the sighting of a white elephant in one of the country's many provinces is immediately reported to the Royal Household Bureau, which will send experts concerned with the carrying out of complicated procedures to ascertain whether it has the characteristics of a "noble" one. ${ }^{33}$ Elephants still take part in certain royal ceremonies, and also play an important role in Buddhism: elephant is a symbol

31 Rupert Gethin, "Cosmology and Meditation: From the Agañña-sutta to the Mahāyāna," History of Religions 36.3 (1997): 211, 217.

32 In India-from where most likely these rules come-the science (śāstra) of the elephants (gaja) was also a very important subject for the royal courts, and the "Hindus treated elephantology as a branch of the Arthaśästra [see, for instance, Arthaśästra, II.1-2, editor's note], the science of statecraft or government." See Franklin Edgerton, The Elephant-Lore of the Hindus (1931; repr. Bangkok: Yale University Press, 2010), 1-2. There are several Sanskrit workssuch as Mätaingalīlā and Hastāyurveda - that fix rules and paradigms that have to be followed by people who have to select and take care of a Royal elephant. In one of them, the Mátaingalīla (I.31), we find an interesting etymology of the word gaja: "because they conquer (ji) and likewise because they roar [garj]." See Edgerton, The Elephant-Lore of the Hindus, 50.

33 See William Warren et al., The Elephant in Thai Life and Legend (Bangkok: Monsoon Editions, 1999), 120-21. 
of intellectual strength (in the form of a gray elephant if it has not yet been tamed, and in the form of a white one if it has), the Buddha himself, in the past, was incarnated as an elephant, and this noble animal is also the "vehicle" of the Buddha's descent to earth for his last birth. ${ }^{34}$ Respect for this animal, therefore, brings benefits in the present life, and in those to come.

In this codex there are images of noble but also non-noble elephants. One of these illuminations shows two elephants that are hardly paragons of beauty: the first, with red eyes and short converging tusks, is absorbed in eating crabs; the second wears an expression regarded as somewhat lacking in intelligence. Both have short tales, a sign of humble ancestry. There is a splendid image of an Uposatha elephant, a member of one of the traditional ten races_or "familes" (kula) —of noble elephants: together with those of the Chaddanta family, members of the Uposatha family are regarded as worthy of becoming one of the seven jewels of the universal sovereign (cakkavatti). ${ }^{35}$ Visible on its hide are the divinities that embody the various anatomical parts of the elephant itself.

One other particularly striking illumination is shown in figure 7, depicting Erāvaṇa (in Pali), known in Hindu mythology as Airāvata. Erāvaṇa is the elephant belonging to Sakka; he is white and has three heads, though he is sometimes shown with thirty-three.

Looking at these splendid manuscripts, and trying to understand the world to which they allude, we shall probably find ourselves wondering how it is possible that the Buddhist tradition, with its austere moral injunctions, highly complex philosophical theories, and deep understanding of the human mind, can coexist successfully with a world of magic, teeming with myths, legends, and prophecies with close links to the forces of nature.

34 The entire sixth chapter of the Lalitavistara is a description of the entrance of the Bodhisatta in his mother's womb in the shape of a white elephant. See P. L. Vaidya, ed., Lalitavistara (Darbhanga: Mithila Institute, 1987), 46-60, and Bijoya Goswami, Lalitavistara. English translation with notes (Kolkata: Asiatic Society, 2001), 61-78.

35 See, for instance, Dhammapada-atthakathā III, 248, in Buddhist Legends, trans. Eugene Watson Burlingame [1921; repr. Delhi: Motilal Banarsidass, 2005], 67), and the Bālapanditasutta in the Majjhimanikaya, III, 174-75) in Middle Length Discourses of the Buddha, trans. Bhikkhu Bodhi [Kandy: Wisdom Publications, 1995], 1024). 


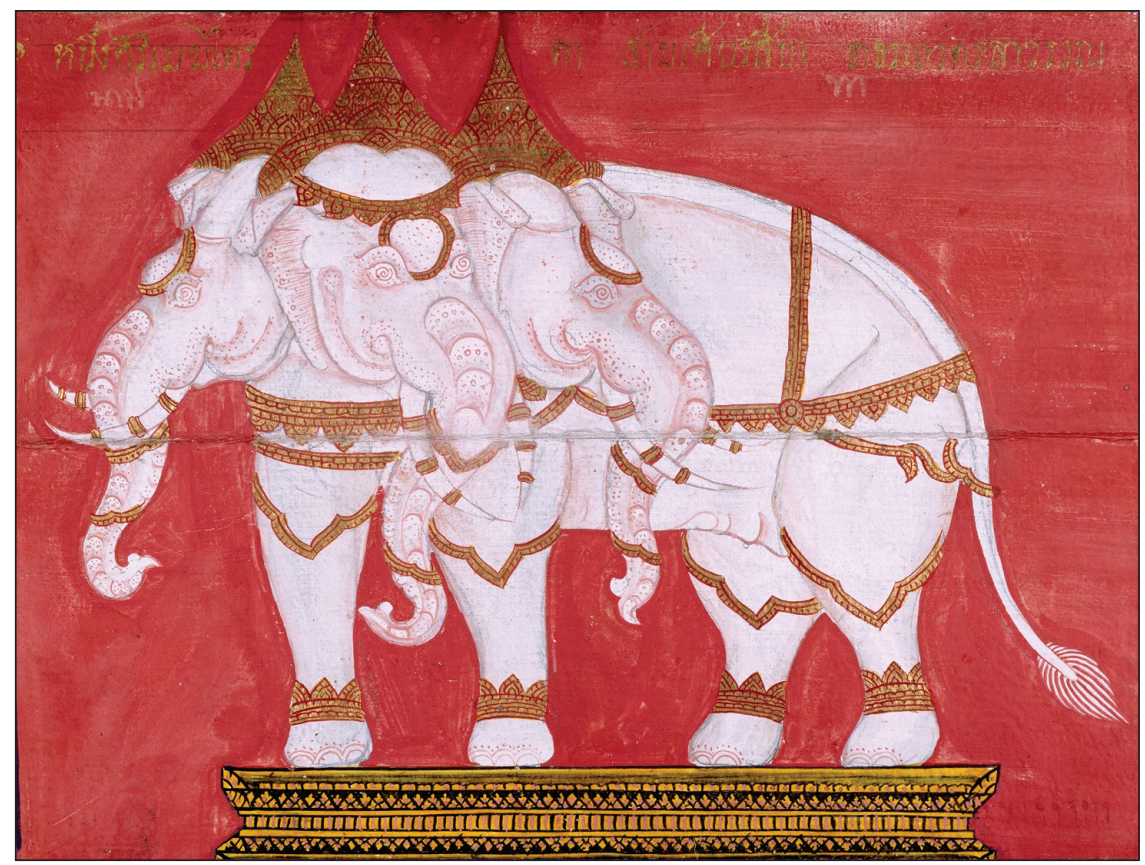

FIGURE 7. The white elephant Erāvaṇa, elephant of Sakka, as depicted in a gajalakșaṇa manuscript. Maurizio Taddei Library, uncatalogued manuscript, Ratanakosin period. Photo courtesy of Luciano Pedicini.

Persistent though it is, this dichotomy is transcended or at least accepted in contemporary Thailand. As a religion, Buddhism has welcomed elements of popular culture, indeed, it derives its vital sap-and, often, an economic support - from just such elements. In fact, these apparent paradoxes reflect a dialectic inherent in the very heart of Buddhism, in the relation between ultimate truth and worldly reality, between the final liberation, which is ineffable, and the infinite series of earthly events that make up the lives of men.

One single idea runs through all these three works: time is a silent vortex that involves and reconfigures all things, bringing the past closer to the present and allowing us in some way to determine our future. Nothing can escape the cyclical changes: even the various hells are not definitive, but subject to the law of impermanence, and to the inviolable human right to development, to the aspiration for, and achieving of, the final liberation. This is one of the meanings of the jätakas in the first manuscript, with their 
images belonging to a past world that necessarily have repercussions for the present one, showing us the most correct and morally fruitful way of being part of it. The same is true of the illuminations in the second manuscript, in which this external world becomes a mirror of the inner one, and all the elements that make it up are transformed into metaphorical images and instruments enabling us to understand our present existence and to exert a beneficial effect upon our future one. Lastly, we have the ancient symbol of the elephant, an emblem of intellectual and moral strength, originally an incarnation of the Buddha but which now stands for the stability of an entire society.

Overwhelmed by the cycles of time, history-according to the popular Thai adage "history often retraces its steps" (ประวัติศาสตร์ซ้ำรอย, pravatisat sam roy) - seems to repeat its plays, in which the same actors rotate in playing the same infinite roles. 


\section{LIST OF MANUSCRIPTS CITED}

Baltimore, Walters Art Museum

W. 716: 192 n. 7

Bangkok, Wat Suthat

Wat Suthat Thep Wararam: 141-42, 142 fig. 15

Berlin, Berlin State Library

Akta III F 17a 1834/1857: 90 n. 21

MIK I 1430-32: 86 n. 12

MIK 14745: 86 n. 12

Ms. or. fol. 333-36: 90, 90 n. 22

Ms. or. fol. 337-38: 91

Ms. or. fol. 557-60: 85 n. 7

Ms. or. fol. 3183-268: 101

Ms. or. fol. $6563: 85$ n.5, 86 n. 12

Ms. or. fol. $6602-3: 86$ n. 12

Ms. or. fol. 7955: 86 n. 12

Ms. or. 10612: 86 n. 12

Berlin, Ethnological Museum

Akte 24/3.94: 97 n. 48

Berlin IC 13972: 96 n. 43

Boston, Boston Public Library

MS pb Med. 35: 260

MS pb Med. 110.1-110.2: 259

MS q Med. 85: 260

Boston, Isabella Stewart Gardner Museum

2.c.3.23: 260

6.T.1: 259

Cambridge, MA, Harvard Art Museum/

Fogg Museum

1954.127.A-B: 259

Cambridge, MA, Houghton Library,

Harvard University

MS Richardson 42: 259
MS Typ 37: 258

MS Typ 956: 259

MS Typ. 215: 258

MS Typ 220: 258

MS Typ 277: 258

MS Typ 439: 209 n. 7, 219 n. 13

MS 584: 258

Thai manuscript \#73: 219 n. 14

Dresden, Dresden State Library

6717-24: 85 n. 4

6726-28: 85 n. 4

6730: 85 n. 4

25888: 85 n. 4

33479 a: 85 n. 4

34575: 85 n. 4

Dresden, Ethnological Museum

6730 Siam: 94

25888 Siam: 100

34575 Siam: 94

Dresden, Staatliche Kunstsammlungen

Ca-129: 88

Dublin, Chester Beatty Library

CB Thai 1302: 188, 196-98, 197 fig. 10,

198 fig. 11

CB Thai 1309: 188-89

CB Thai 1310: 188, 189-90

CB Thai 1319: 189, 190-93, 191

figs. 8-9,

CB Thai 1330: 179-87, 180 figs. 3-4, 181

figs. 5-6, 182 fig. 7

CB Thai 1331: 198-99

CB Thai 1343: 188, 199, 200 fig. 12

CB Thai 1349: 193-94

CB Thai 1351: 194-95

CB Thai 1352: 195-96 
Cicuzza: Thai Manuscripts in Italian libraries: Three Manuscripts from G.E

\section{4 | Journal for Manuscript Studies}

CB Thai 1353: 200

CB Thai 1354: 200-201

Gotha, State Archive

Ms. As. orient. No. 33: 92 n. 28

Hamburg, Ethnological Museum

13.54:2-4: 85 n. 6

16.40:5: 85 n. 6

1532:08: 85 n. 6

1532:08a: 85 n. 6

3033:07: 85 n. 6

6717-28 Siam: 92 n. 30

A 26: 85 n. 6

A 46: 92

A 903-4: 85 n. 6

Hirado, Matsura Historical Museum

A replica of the Horyuji Sanskrit

manuscript. Paper manuscript.: 164-65,

166 fig. 4, 167

Vessantara Jātaka. Paper manuscript:

163-64, 165 fig. 3

Kyoto, Omiya Library, Ryukoku University

Phra Malai. Paper manuscript (samut

khoi): 172, 173 fig. 8

London, British Library

Add. MS 27370: 27

Add. MS 20698: 247

IOR L/MAR/A/XIII, ff. 28/29: 26

MS Pali 207: 27

Or 6942: 29

Or 11827: 26

Or 11828: 27

Or 13652: 27

Or 14068: 27

Or 14179: 27

Or 14528-29: 27

Or 14613: 27

Or 14722: 27

Or 14732: 27

Or 14559: 27

Or 14664: 27
Or 15245: 27

Or 15749: 29

Or 16009: 27

Or 16552: 27, 39-48, 42 fig. 5, 43 fig. 6, 44 fig. 7, 47 fig. 8,48 fig. 9

London, Lambeth Palace Library

MS. 461: 242, 244

MS. 528: 245

MS. 1176: 242-3, 245-6

MS. 1177: 242

MS. 1182: 245

MS. 1183: 242

MS. 1186: 245

MS. 1187: 242-43

MS. 1188: 242-43, 246

MS. 1191-92: 245

MS. 1194: 245

MS. 1195: 242

MS. 1197: 242

MS. 1199: 242, 244

MS. 1205: 244-45

MS. 1214: 242

MS. 2794: 242, 244

MS. 2795: 244

MS. Sion L40.2/G1: 243

MS. Sion L40.2/G5: 242-43

MS. Sion L40.2/G6: 242-44

MS. Sion L40.2/G7: 243, 245

MS. Sion L40.2/G9: 242-44

MS. Sion L40.2/G10: 242

MS. Sion L40.2/G11: 243, 246

MS. Sion L40.2/G12: 242-44

London, Royal Asiatic Society

RAS Thai MS 2: 58, 71 appx. 2

RAS Thai MS 4-6: 71 appx. 2

RAS Thai MS 7: 71-72 appx. 2

RAS Thai MS 8-9: 72 appx. 2

RAS Thai MS 10.A-B: 72 appx. 2

RAS Thai MS 13: 72 appx. 2

RAS Thai MS 14: 72-73 арpx. 2

RAS Thai MS 15-20: 73 appx. 2 
RAS Thai MS 21: 73-74 appx. 2

RAS Thai MS 21.A-C: 74 appx. 2

RAS Thai MS 21.E: 74 appx. 2

RAS Thai MS 30: 74 appx. 2

London, Wellcome Library

9541: 70 appx. 2

MS 801: 70 appx. 2

Thai 1-4: 62 appx. 2

Thai 5: 62-63 appx. 2

Thai 5/10818: 70 appx. 2

Thai 6-11: 63 appx. 2

Thai 12: 63-64 appx. 2

Thai 13-18: 64 appx. 2

Thai 19-30: 65 appx. 2

Thai 31-37: 66 appx. 2

Thai 38-44: 67 appx. 2

Thai 45-51: 68 appx. 2

Thai 52: 68-69 appx. 2

Thai 53-59: 69 appx. 2

Thai 60-61: 70 appx. 2

Thai 64: 70 appx. 2

WMS Pāli Thai 22: 71 appx. 2

WMS Thai Lao: 70 appx. 2

Manchester, John Rylands Library

Pali MS 82: 79-80 appx. 2

Siamese (Thai) MS 1-4: 77 appx. 2

Siamese (Thai) MS 5-10: 78 appx. 2

Siamese (Thai) MS 11: 78-79 appx. 2

Munich, Bayerische Staatsbibliothek

(Bavarian State Library)

BSB cod.siam 1: 91 n. 25

BSB cod.siam 6, 8, 9, 13, 14, 17, 18, 31:

86 n. 11

BSB cod.siam 33: 87 n. 15

BSB cod.siam 35: 85, 85 n. 9, 86 n. 11

BSB cod.siam 36, 93, 106, 107, 108, 110,

111: 86 n. 11

BSB cod.siam 98: 86

BSB cod.siam 129: 85

BSB cod.siam 130: 86 n. 11

BSB cod.siam 149: 85
BSB cod.siam 189: 85

BSB cod.siam 193: 85

Naples, Biblioteca Maurizio Taddei,

University of Naples “L’Orientale”

Uncatalogued manuscript, Ratanakosin period: 113-18, 115 fig. 1, 116 figs. 2-3, 117 fig. 4, 119 fig. 5

Uncatalogued manuscript, Ratanakosin period: 118-21, 120 fig. 6

Uncatalogued manuscript, Ratanakosin period: $121-22,123$ fig. 7

New York, Burke Library of the Union

Theological Seminary

Manuscript 21 (Poleman 6376): 215

Manuscript 22 (Poleman 6399): 215

Museum KP23.9/Library No. 1177: 215

New York, New York Public Library

Thai/Spencer Collection manuscript

numbers 6, 7, 22, 25: 214

Siamese Manuscript no. 1: 214

Siamese Manuscript no. 3: 214

Siamese Manuscript no. 4: 214

Osaka, National Museum of Ethnology H0009692 (NME9692): 171

Phra Malai. Paper manuscript (samut khoi): 171, 172 fig. 7

Oxford, Bodleian Library

BODL. Dep. Stol. 111: 74-75 appx. 2

BODL. Dep. Stol. 112: 75 appx. 2

BODL. Dep. Stol. 113: 75 appx. 2

BODL. Ms. Asiat. Misc. a. 8(R):

75 appx. 2

BODL. Ms. Asiat. Misc. a. 9(R):

75 appx. 2

BODL. Ms. Asiat. Misc. a. 11(R):

76 appx. 2

BODL. Ms. Asiat. Misc. a. 23(R):

76 appx. 2

BODL. Ms. Asiat. Misc. a. 25(R):

76 appx. 2 
Cicuzza: Thai Manuscripts in Italian libraries: Three Manuscripts from G.E 266 | Journal for Manuscript Studies

BODL. Ms. Asiat. Misc. c. 16(R):

76 appx. 2

BODL. Ms. Asiat. Misc. c. 27(R):

76 appx. 2

BODL. Ms. Pali. a. 27(R): 20

BODL. Ms. Pali. a. 31(R): 76-77

appx. 2

BODL. Ms. Pali. a. 50(R): 77 appx. 2

Pakkret, Thailand

A Mon palm-leaf manuscript from

Pakkret, Thailand: 143 figs. 16-18

Phetchaburi, Thailand, Wat Pak Khlong

1. Miscellaneous chants, late Ayutthaya period (Wat Pak Khlong No. 3): 136-38, 137 figs. 5-6, 137 n. 19

2. Miscellaneous chants, early Bangkok period (Wat Pak Khlong No. 1):

136, 138-40, 139 figs. 7-9, 140 figs.

$11-14$

3. Delineation of monastic boundaries, CE 1874: 136, 143-6, 144 fig. 18, 145 figs. 19-20, 146 fig. 22, 157 figs. $22-23$

4. An astrological manuscript written in yellow pigment, early twentieth century: 136, 146-48, 148 fig. 24

5. Phra Malai Klon Suat, in Thai language, late Ayutthaya Khom script: 136
Philadelphia, University of Pennsylvania

Museum of Archaeology and Anthropology Obj. \# 29-170-11: 203 fig. 1, 205 fig. 2, 206 n. 3

Obj. \# 29-170-12: 207 n. 5

Ms. 89-13-251: 235-37

Philadelphia, University of

Pennsylvania Library

Ms. Coll. 390, Item 2990: 223, 223 n. 20

Ms. Coll. 390, Item 2991: 224-26,

224 n. 23

Ms. Coll. 390, Item 2992: 223-24,

224 n. 21

Ms. Coll. 990, Item 5: 229, 233, 235

Stuttgart, Linden Museum

Hs. 56816 siam: 98

Hs. 56817 siam: 98

Takasago, Jurinji temple

Vessantara Jātaka: 168-69, 169 fig. 5

Takasago, Shinjoji temple

Vessantara Jātaka: 169, 170 fig. 6

Takasago, Zenryuji temple

Bra mangaladipanī-ațthakathāmañgalasūtra, phuuk 18: 169-70 n. 41

Wellesley, MA, Wellesley College, Margaret Clapp Library MS 33: 259 